\title{
USE OF PERSONAL PROTECTIVE EQUIPMENT BY GAS STATIONS WORKERS: A NURSING CONTRIBUTION ${ }^{1}$
}

\author{
Laurelize Pereira Rocha², Marta Regina Cezar-Vaz ${ }^{3}$, Marlise Capa Verde de Almeida ${ }^{4}$, Clarice Alves Bonow ${ }^{5}$, \\ Mara Santos da Silva ${ }^{6}$, Valdecir Zavarese da Costa
}

${ }^{1}$ Extracted from the thesis - Gas stations workers: individuals exposed to benzene, Nursing Graduate Program, Federal University of Rio Grande (FURG), 2012.

${ }^{2}$ Doctoral student, Nursing Graduate Program, FURG. Scholarship provided by Research Support Foundation of Rio Grande do Sul (FAPERGS). Rio Grande do Sul, Brazil. E-mail: laurelize@gmail.com

${ }^{3}$ Ph.D. in Nursing. Associate Professor, Nursing School, FURG. Rio Grande do Sul, Brazil. E-mail: cezarvaz@vetorial.net

${ }^{4}$ Doctoral Student, Nursing Graduate Program, FURG. Technical Nurse at the Laboratory of Nursing Practices, Nursing School, FURG. Rio Grande do Sul, Brazil. E-mail: marlisealmeida@msn.com

${ }^{5}$ Ph.D. in Nursing. Professor, Nursing Program, Federal University of Pampa (UNIPAMPA). Uruguaiana, Rio Grande do Sul, Brazil. E-mail:enfcla@yahoo.com.br

${ }^{6}$ Ph.D. in Nursing. Associate Professor, Nursing School, FURG. Rio Grande do Sul, Brazil. E-mail: marare@brturbo.com.br

${ }^{7}$ Ph.D. in Environmental Education. Professor, Nursing Program, UNIPAMPA. Rio Grande do Sul, Brazil. E-mail: valdecircosta@ unipampa.edu.br

ABSTRACT: This study's objective was to identify the use of personal protective equipment by gas stations' workers in the city of Rio Grande, RS, Brazil. This quantitative, descriptive and exploratory study was conducted with 221 workers from 22 gas stations using a questionnaire and non-participative and symmetrical observation. Descriptive statistics were used in the analysis and question quality was controlled through Cronbach's alpha test, which obtained a result of 0.96 . The results indicate a predominance of multitasking, while workers self-reported the use of boots, aprons, gloves, masks, goggles, earplugs and uniforms. Observation, however, showed incoherence in the workers' reports, since only boots and uniforms were actually used. The results show there is a need for nurses to implement protective and preventive actions to assure workers are not exposed to risks and hazards, while also encouraging health surveillance.

DESCRIPTORS: Occupational health. Protective devices. Filling station. Nursing.

\section{UTILIZAÇÃO DE EQUIPAMENTOS DE PROTEÇÃO INDIVIDUAL POR FRENTISTAS DE POSTOS DE COMBUSTÍVEIS: CONTRIBUIÇÃO DA ENFERMAGEM}

\begin{abstract}
RESUMO: Objetivou-se identificar a utilização de equipamentos de proteção individual por atendentes/frentistas de postos de combustíveis da cidade do Rio Grande-RS. Trata-se de um estudo quantitativo, exploratório e descritivo, realizado com 221 frentistas de 22 postos de combustíveis, por meio de questionário e registro de observação não participante e sistemática. Para a análise foram realizadas a estatística descritiva e o controle de qualidade das questões, por meio do teste Alpha de Cronbach, obtendo-se o resultado de 0,96 . Verificou-se a predominância da multifunção e a utilização autorreferida de botinas, avental, luvas, máscara, óculos, protetor auricular e uniforme. A observação confirmou somente o uso de botinas e uniformes, constatando-se incoerência. Os pontos levantados demonstram a necessidade da atuação do enfermeiro, por meio de ações de proteção e prevenção de riscos e agravos à saúde do trabalhador, incentivando a vigilância em saúde.
\end{abstract}

DESCRITORES: Saúde do trabalhador. Equipamentos de proteção. Posto de combustível. Enfermagem.

\section{UTILIZACIÓN DE EQUIPAMIENTOS DE PROTECCIÓN INDIVIDUAL POR EMPLEADOS DE ESTACIÓN DE SERVICIO: CONTRIBUCIÓN DE LA ENFERMERÍA}

RESUMEN: Se objetivó identificar la utilización de equipamientos de protección individual, por asistentes/ empleados de gasolinera de
la ciudad de Rio Grande-RS. Se trata de un estudio cuantitativo, exploratorio, descriptivo, realizado con 221 trabajadores de 22 estaciones
de servicio, por medio de cuestionario y registro de observación no participante y sistemático se dio. Para análisis fueram realizadas
la estadística descriptiva y el control de calidad de las preguntas por medio del test Alpha de Cronbach, obteniendose el resultado de
0,96. Se verificó la predominancia de la multifunció y la utilización de botas, delantal, guantes, máscara, lentes, protector auricular
y uniforme, conforme autoreferido. La observación confirmó únicamente el uso de botas y uniformes, constatandose inconsistencia.
Los puntos planteados demuestran la necesidad de actuación de las enfermeras, a través de acciones de protección y prevención de
los riesgos y peligros para la salud del trabajador, estimulando la vigilancia de la salud. DESCRIPTORES: Salud laboral. Equipos de seguridad. Gasolineras. Enfermería. 


\section{INTRODUCTION}

The environment of gas stations exposes gas station attendants to innumerous risks and health hazards, which should be considered harmful to the health status of these workers. Among the risks are: contact with fuels and other chemical products, remaining close to fuel pumps, noise, heat, cold, risk of being run over, robbery, repetitive movements, standing for long hours, and work overload due to the different functions they perform..$^{1-2}$ There are chemical products to which these workers are exposed, such as aromatic hydrocarbons, benzene, toluene and xylene (BTX), components of gasoline and chemical solvents. ${ }^{3}$ The chemical agent benzene, which poses a high risk to human health, even in small amounts, is an colorless, volatile, soluble, flammable liquid with high carcinogenic potential. It is present in the air through cigarette smoke, gasoline fumes, and emissions of automotive engines, in gas stations, and chemical industries, among others ${ }^{2-3}$ Automobiles are considered to be the main source of benzene. Therefore, we note the continuous exposure of individuals working at gas stations during work hours. ${ }^{4}$

Exposure to benzene has been subject to environmental and occupational control worldwide due to being a contaminant and its harmful potential related to the possibility of causing diseases, such as myeloid leukemia and lymphoblastic leukemia. ${ }^{4}$ Data from the National Cancer Institute of Brazil (INCA, as per its acronym im Portuguese) indicate that benzene, toluene and xylene are the contaminants that pose the highest risk of cancer development due to occupational and environmental exposure. ${ }^{3}$ The toxicity of benzene does not depend on the route it is introduced into the organism, though the main routes are respiratory from the inhalation of fumes, the digestive tract and skin. Contamination through skin depends on skin integrity, hydration, and temperature. ${ }^{5}$ Such exposure may cause gastrointestinal disorders such as stomach aches, heartburn and poor digestion; allergies and itching skin may be observed, especially on the hands; changes in the central nervous system such as dizziness may be observed, while the respiratory system may be compromised. ${ }^{6}$

Due to uncertainty in regard to safe levels of exposure to benzene, differences among individuals in terms of sensitivity to absorption are con- sidered. ${ }^{7}$ There is a prevention model that, a priori, does not recognize any safe parameter of exposure to benzene. Under Brazilian law, the epidemiological surveillance of populations exposed to benzene is considered a way to identify and control at an early stage health problems arising from this work environment. This surveillance process is intended to minimize exposure of workers to occupational risks and diseases through individual and collective preventive measures. ${ }^{8}$

In the context of gas station workers, attention is drawn to surveillance health actions and programs intended to reduce exposure to benzene. ${ }^{7}$ Therefore, education in regard to the appropriate use of Personal Protective Equipment (PPE), hygiene and collective protection measures is essential, as is encouraging their use. From this perspective, nursing professionals can apply their clinical knowledge and implement individual and collective interventions to influence the thinking and actions of subjects/workers in relation to their own health, promoting self-transformation through the acquisition of knowledge concerning the health-work-disease continuum. $^{9}$

There is scientific nursing and clinical support that can be applied in different fields within public and occupational health. Like the focus of this study, gas stations, there are environments seldom explored and are not part of the daily practice of nursing professionals. Nursing professionals have unique features and can be effective in recognizing and seeking strategies to encourage individual and social transformations in the field of occupational health.

Therefore, there is a need to identify the context of gas station attendants to devise intervention strategies to promote health and prevent risk and disease that are the result of the occupational environment. For that, the following question guided this study: what personal protective equipment do gas stations' workers use in the work place? This study's objective was to identify the use of personal protective devices by gas station workers in the city of Rio Grande, RS, Brazil.

\section{METHOD}

This exploratory, descriptive and quantitative study was conducted with $22(65 \%)$ of the 
34 gas stations located in Rio Grande, RS, Brazil. Four of these refused to participate and eight were classified as loss since personal contact, or contact through telephone or email, was not established after six months of attempts. None of these facilities agreed to sign their refusal.

The population of gas stations' workers in the city is approximately 340 workers, 221 of which constituted the study's sample distributed according to the companies' functional staff. The workers were selected according to the following criteria: individuals working directly with fuel pumps with a minimum weekly workload of 30 hours regardless of their shift. The sample was computed using StatCalc in the EpiInfo Program, version 3.5.2. A level of confidence of $95 \%$ was considered with a sample size of 180 individuals.

Each facility was contacted and asked to authorize the study. A pilot study with 20 workers was conducted in two gas stations located in the city. These were included in the total sample because there were no changes in the questionnaire for data collection. The members of the research group responsible for the study were previously trained for the fieldwork, which was performed in the second semester of 2010 using a structured questionnaire addressing the following variables: sex, age, race, schooling, marital status, and other questions related to the individuals' characteristics; work characteristics; time in job function; workload and wage income; variables related to the organization of the work process; and use of PPE. This last section was structured in accordance with the Regulating Norm $(\mathrm{RN})^{6}$, which regulates aspects related to the health surveillance of workers exposed to benzene and the use of PPE as protective and prevention measures against risk exposure in the work place. ${ }^{10-11}$

To measure the reliability of the questions, Cronbach's alpha was performed, the result of which was 0.96 , showing that the variance of scores is explainable. ${ }^{12}$ In addition to the questionnaire, data collection included non-participant observation during everyday circumstances in the public areas, supporting the study to describe and clarify how the things in fact occur and thereby complementing data provided in questionnaires. In this manner, the study provides more consistent knowledge to organize and analyze data. ${ }^{13}$ A script was used to guide observation toward aspects related to the study's problem. A total of 213 hours and 15 minutes of observation were recorded; an average of ten hours in each gas station. Observation was mainly performed during the day, between $8 \mathrm{am}$ and $8 \mathrm{pm}$, including Sundays and holidays during working hours, comprising a total of 163 workers. The Statistical Package for the Social Sciences (SPSS), version 19.0, was used to organize and analyze data. Descriptive analysis was chosen and absolute frequencies and percentages were obtained.

Observation notes were recorded in a field diary and immediately coded into different categories in order to make clear the differences and similarities found among the observations and to support analysis based on the definition of the study's problem. ${ }^{13}$ These notes enabled the characteristics of the work to be quantified within the specific theme: the use of PPE by gas station attendants.

This is part of a larger project titled "Health, risks and occupational diseases: an integrated study in different work places." It was approved by the Institutional Board Review at the Federal University of Rio Grande (FURG) according to protocol n. 109/2010; the participants signed free and informed consent forms prior to data collection and were ensured of confidentiality and anonymity.

\section{RESULTS}

Most workers (90.5\%) were male, while 21 (9.5) were female. Ages ranged between 19 and 64 years old with an average of 30 years old $( \pm$ 9.58). In regard to schooling, $111(50.2 \%)$ completed high school; 38 (17.2\%) completed middle school; 32 (14.5\%) did not complete high school; $29(13.1 \%)$ did not complete elementary school; eight $(3.6 \%)$ individuals attended some college; one $(0.5 \%)$ worker had a bachelor degree and one $(0.5 \%)$ had a specialization. Table 1 presents the characteristics of the work performed by gas station workers. 
Table 1 - Characteristics of the work performed by gas station workers. Rio Grande-RS, Brazil, 2010

\begin{tabular}{|c|c|c|c|}
\hline Variables & Categories & $\mathbf{n}$ & $\%$ \\
\hline \multirow{8}{*}{ Function(s) performed } & Attendant & 180 & 81.4 \\
\hline & Car wash & 3 & 1.4 \\
\hline & Lubrication & 5 & 2.3 \\
\hline & Lane manager & 8 & 3.6 \\
\hline & Wash and fuel cars & 24 & 1.8 \\
\hline & Cashier and fuel cars & 15 & 6.8 \\
\hline & Lubricate and fuel cars & 4 & 1.8 \\
\hline & $\begin{array}{l}\text { Fuel cars, administrative assistance and general } \\
\text { services }\end{array}$ & 2 & 0.9 \\
\hline \multirow{8}{*}{ Activities performed } & Fuel cars & 221 & 100 \\
\hline & Express wash & 20 & 9 \\
\hline & Ramp wash & 7 & 3.2 \\
\hline & Oil change & 60 & 27.2 \\
\hline & Cashier & 42 & 19.5 \\
\hline & Service in convenience store & 10 & 5 \\
\hline & Administrative assistant and general services & 5 & 2.4 \\
\hline & Cleaning & 9 & 4.5 \\
\hline \multirow{4}{*}{ Time working in the sector } & Less than 1 year & 72 & 32.6 \\
\hline & From 1 to 5 years & 84 & 38 \\
\hline & From 5 to 10 years & 32 & 14.5 \\
\hline & More than 10 years & 33 & 14.9 \\
\hline \multirow{4}{*}{ Time performing job function } & Less than 1 year & 63 & 28.5 \\
\hline & From 1 to 5 years & 90 & 40.7 \\
\hline & From 5 to 10 years & 27 & 12.2 \\
\hline & More than 10 years & 41 & 18.6 \\
\hline \multirow{5}{*}{ Workload } & Daytime 6 hours & 81 & 36.7 \\
\hline & Daytime 8 hours & 66 & 29.9 \\
\hline & Nighttime 6 hours & 48 & 21.7 \\
\hline & Nighttime 8 hours & 32 & 14.5 \\
\hline & Daytime and nighttime 6 hours & 29 & 13.1 \\
\hline \multirow{4}{*}{ Extra hours } & Daytime 12 hours & 53 & 24 \\
\hline & Nighttime 12 hours & 34 & 15.4 \\
\hline & On duty at the weekends and holidays & 78 & 35.3 \\
\hline & Rotating shifts & 38 & 17.2 \\
\hline \multirow{4}{*}{ Wage income } & Up to $R \$ 750.10$ & 102 & 46.2 \\
\hline & From $\mathrm{R} \$ 750.10$ to $\mathrm{R} \$ 1,500.20$ & 109 & 49.3 \\
\hline & From $\mathrm{R} \$ 1,500,20$ to $\mathrm{R} \$ 2,250.30$ & 2 & 0.9 \\
\hline & Ignored & 8 & 3.6 \\
\hline
\end{tabular}

In regard to the self-reported use of PPE, boots was the device most frequently mentioned (202 workers/91.4\%), followed by aprons (89 workers $/ 40.3 \%$ ) (Figure 1). The workers also mentioned other PPE: 18 (8.5\%) workers reported the use of uniforms (pants, T-shirts, jacket and hat); 
nine $(4.07 \%)$ workers reported the use of hand lotion; seven $(3.2 \%)$ workers reported the use of overalls; two $(0.9 \%)$ reported the use of motorcycle helmets; three $(1.5 \%)$ reported they wore their own clothes; one $(0.5 \%)$ reported the use of waterproof clothing (motorcycle); one (0.5\%) reported the use of chemical gloves, and another $(0.5 \%)$, reported the use of water-repellent boots.

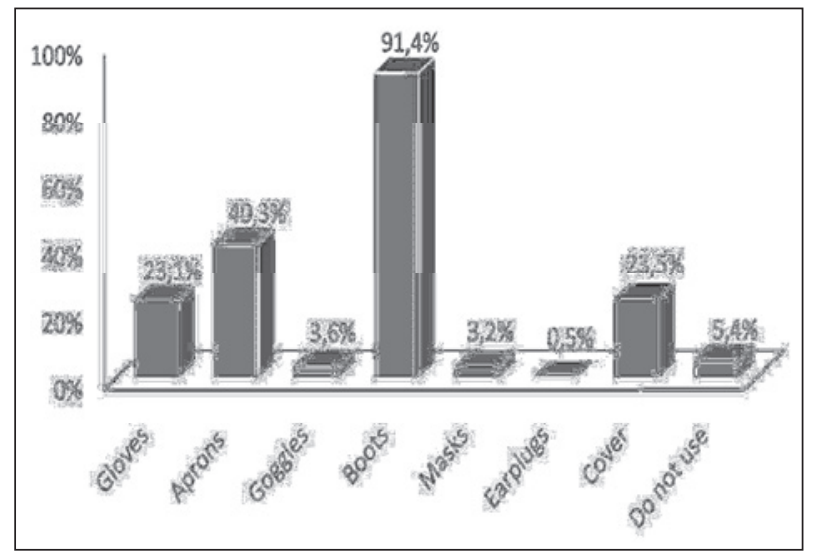

Figure 1 - Frequency PPE is used by gas station workers. Rio Grande-RS, Brazil, 2010

Reasons PPE is not used by some of the interviewees are provided by 12 workers: six $(2.7 \%)$ reported there is no PPE available at work; three $(1.4 \%)$ reported the company does not require the use of PPE: two $(0.9 \%)$ considered it to be troublesome/ uncomfortable; and one $(0.5 \%)$ worker did not use it because he was in training. We highlight the PPE provided by the company and which the workers consider being necessary (Figure 2). In regard to PPE the workers considered to be necessary: 29 (13.2\%) indicated raincoat; 28 (12.6\%), uniform (pants, T-shirt, jacket and hat); 14 (6.3\%) hand lotion; eight (3.6\%) no PPE necessary; two $(0.9 \%)$ overalls; and two $(0.9 \%)$ mentioned the use of motorcycle helmet.

The observation process enabled capturing the organizational structure of the work performed by the workers based on ample analysis per gas station. Multitasking was the main characteristic of 21 gas stations, since the workers would fuel cars, charge for the service, wash windshields, check oil and fluids, clean the work environment (floor, store and bathrooms), clerk in the convenience store, and take care of the cash register and sell products (e.g. coal, fire extinguishers, automotive oil, etc.), among others. Other characteristics refer to work hours: no fixed schedule was observed in four gas stations; in nine stations, the workers stood up most of the time or even throughout the workday due to the need to manage administrative work.

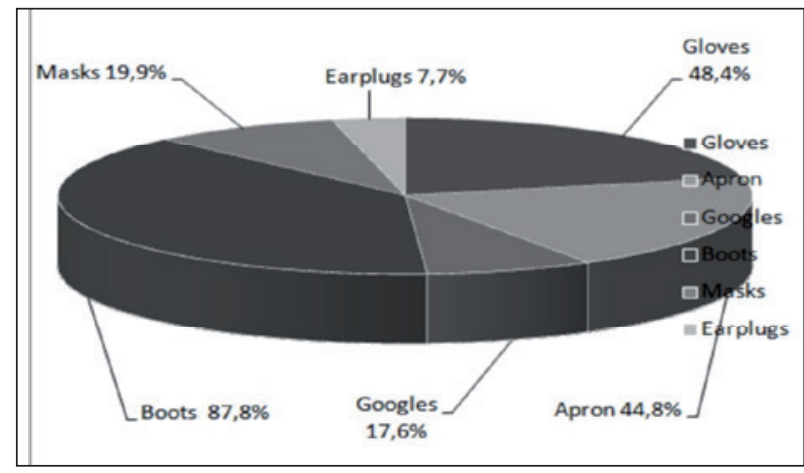

Figure 2 - PPE provided by the companies and deemed necessary by the gas station workers. Rio Grande-RS, Brazil, 2010

We observed workers in three gas stations fueling more than one vehicle at the same time. In three stations workers had their meals while standing at a lane. In another station, workers did not have time for a meal due to the large number of duties they had, while in another station there was no proper place for the workers to have their meals. In regard to the use of PPE, a uniform was individual protection in 20 gas stations, though not all workers made use of uniforms. Additionally, the T-shirts that compose the uniforms either had short sleeves or long sleeves were used but rolled up.

Certain notes concerning the observations deserve to be highlighted: one gas station did not provide boots or uniforms; in another, the workers used their own "motorcycle" clothing to protect them from rain; a single worker from another station used a mask, though only when lubricating vehicles. Considering the individuals who did not use PPE, several situations were observed: the rags used by workers to clean their hands remained on the fuel pumps the entire time. We also verified, in one station, that the workers remained the entire time at work with their hands soiled with fuel; in another station, the workers had snacks in the fuel lane without washing their hands.

We observed one worker whose face and eyes mucosa came into contact with gasoline when filling a container (an empty bottle) for a client. This worker spontaneously reported that it was not the first time. In another two stations, a worker's eye mucosa was splashed with oil when lubricating a vehicle (Figure 3). 


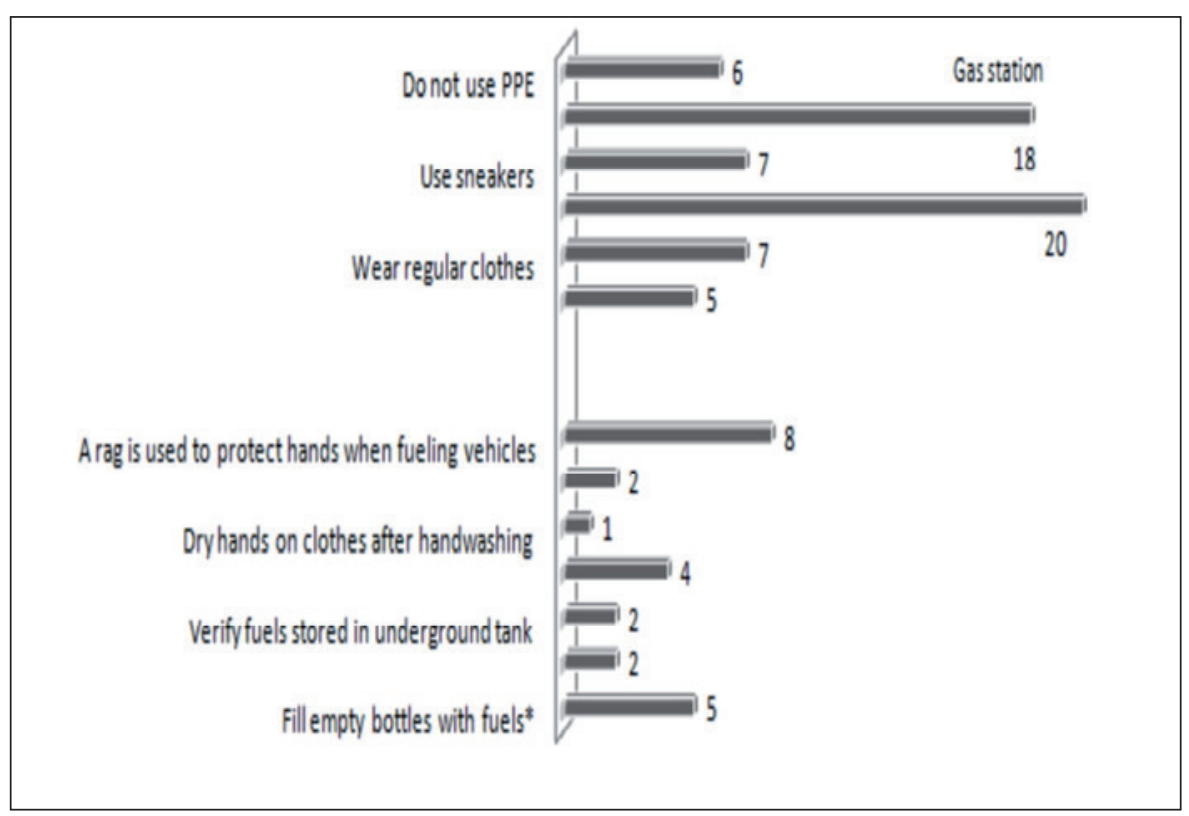

Figure 3 - Items recorded in the observation of gas stations concerning the use of PPE and situations when PPE is not used by the gas station workers. Rio Grande-RS, Brazil, 2010

\section{DISCUSSION}

Most workers in this study were white male and young adults, which is in agreement with other publications. ${ }^{14-15}$ Studies with gas station workers, truckers and other workers exposed to benzene show that some professions are more common among men, which may be explained by the fact these professions present more evident risks if compared to other professions. Exposure to chemical agents such as benzene, toluene and xylene among women working in petrochemical resulted in the birth of under weight children. ${ }^{16}$

In regard to education, completed high school was the most common level of education among the workers and there was no statistical significance when this variable was associated with the use of PPE. According to the results of another study, ${ }^{14}$ individuals with this level of education are aware that PPE is required to protect from occupational exposure. Multitasking was observed among the work characteristics, which corroborates another study ${ }^{2}$ that indicates that multitasking associated with working conditions is a factor generator of physical disorders (work dynamics), psychological disorders (high demand from the company, clients and co-workers), and physiopatological disorders due to the manipula- tion of chemical products than can lead to severe health problems. In the item related to time working in the sector and performing the job function, we observed workers with more than 10 years in the job function, which requires that attention be paid to their health. One study ${ }^{14}$ shows a high level of hippuric acid (biological indicator of toluene) in a worker performing his job function for 21 years, characterizing a high level of contamination due to longer exposure. Another study ${ }^{15}$ shows that cumulative exposure to low levels of benzene may cause leukemia.

Most gas station workers worked six hours during daytime, followed by eight hours during daytime. When there were extra hours, 12 hours during daytime predominated. According to Art. 58, Consolidation of Labor Laws (CLT, as per its acronym in Portuguese ), work hours should not exceed eight hours daily. ${ }^{17}$ According to NR-15, due to benzene's proven carcinogenic potential, there are no safe levels of exposure, which reinforces the need to promote strategies to minimize the exposure of workers to benzene and justifies a review of time of exposure, due to the cumulative factor of this chemical agent in an organism. ${ }^{10}$ Observations also reveal irregular work schedules, which impede workers from having another occupation (job or school), thus making the work even more demanding for the gas station worker, 
possibly leading to the occurrence of occupational accidents and disease caused by physical, psychological or social harm.

Observation also showed there is a lack of an appropriate place and/or time for meals. Paragraph $1^{\text {st }}$ of Art 71 CLT provides that workers with a workload from four to six hours have the right to a 15 minute break from work for a snack and at least one hour, and two hours at most, for workers with more than six hours of continuous work, with the exception of when there is a collective agreement for longer intervals for workloads of up to four continuous hours of work. ${ }^{17}$ In this sense, we note that work organization may minimize psychological, physical and social effects, reduce the time of exposure to chemical agents (especially to benzene) and to occupational work risks caused by long workloads or poorly elaborated schedules.

The wage range of gas station workers is based on the Collective Labor Agreement of 2010/2011 for workers in the retail trade of fuels of Rio Grande do Sul. ${ }^{18}$ The wage may be another reason that generates high turnover in this category of workers, especially given the activity's high demand and risks involved; that is, the salary is just not worth it. ${ }^{2}$ The stipulated minimum wage is $\mathrm{R} \$ 577.00$ plus hazard pay that corresponds to $30 \%$ additional monthly remuneration. Paragraph 1, Art. 193 CLT, establishes that dangerous activities are those whose nature or methods require workers to be in constant contact with flammable or explosive products in conditions of high risk. ${ }^{17}$ According to NR-16, workers who remain in risk areas, even if they do not directly manipulate fuel pumps, are entitled to a hazard pay. ${ }^{11}$ We view gas station workers as performing an unhealthy activity because, according to Art 189 CLT, unhealthy activities or operations are those, which given their nature, work conditions or methods, expose workers to agents that are harmful to health above tolerance limits established by the nature or intensity of the agent and time of exposure to its effects. ${ }^{17}$ Because benzene is a chemical agent, the maximum tolerance of which, intensity and time of exposure are defined only as a technological reference and, in fact, there is no safe level of exposure, the activities performed by these workers justify the adoption of PPE to reduce the intensity of exposure. ${ }^{17}$

In regard to the use of $\mathrm{PPE}$, the use of boots predominated, consonant with one study ${ }^{14}$ that also reports the same observations concerning the workplace. In addition to the use of boots, $40.3 \%$ of the workers used aprons during their activities, a habit to be encouraged among other workers. Aprons are a protective measure against exposure to benzene through skin contact and there is evidence from one study indicating that contamination is reduced when overalls are changed every work shift. ${ }^{19}$ We also note that most workers identify uniforms as being PPE, however the arms remained exposed as the sleeves are either short sleeves or long sleeves were used rolled up, revealing a lack of concern or information on the part of workers who are in direct contact with fuel. Therefore, authors ${ }^{20}$ recommend individual protection, especially of hands and forearms, given benzene's high level of permeability.

PPE protect professionals from risk and harm to health in the workplace and is among the main equipment protecting the most vulnerable routes of exposure against chemical products that are used in gas stations, such as: a hood for the head and neck; face shield and goggles; shoes; gaiters pants; overalls; safety kit (pants, jacket or pullover); respirator; air purifier; and gloves. These devices should be provided by companies to their employees free of cost, according to the needs of the task performed. ${ }^{11}$ The NR-6, however, does not establish specific PPE to be used by workers exposed to benzene, as there is no NR establishing preventive procedures or measures to protect gas stations workers. One study using laboratory exams of gas station workers confirms the correlation of the non-use of PPE and intoxication by toluene or metil benzene, both components of gasoline.$^{14}$ When asked, the workers participating in this study reported the use of masks and gloves, among other PPE, however, such statements were not fully confirmed by observation. On the other hand, when the workers were asked about PPE provided by the companies, which they deemed necessary, they report other items, such as masks, gloves, aprons, earplugs and goggles. The answer encourages reflection concerning the level of knowledge of these workers regarding the risks and hazards to which they are exposed. According to one study ${ }^{21}$, there is a need to clarify the work activity and time of exposure to substances used in the process because the population usually does not have knowledge concerning such harm or neglects the harm, ignoring the risk of 
disregarding the causal nexus. We understand that when workers realize their own exposure to occupational risks, they become co-responsible in the prevention of diseases and accidents and in health promotion. ${ }^{22}$

Even though most workers report the use of PPE, those who do not use the equipment allege the company does not provide the equipment; the company does not enforce its use; PPE is annoying/uncomfortable; or that equipment is not used during training, corroborating a prior study..$^{14}$ In the face of several situations observed in the environment of gas stations concerning the lack of PPE use and inappropriate self-care measures, we verify the need for health professionals to implement interventions, revealing a field for nursing professionals to provide health education, instructing workers about the chemical products used in this environment, especially benzene, one of the main components of gasoline. Among other actions, nurses can bring educational measures to workers, through the acquisition of knowledge concerning the risks to which they are exposed.

The attitudes of workers such as eating at the lane they are responsible for, lack of appropriate hand hygiene before handling food ${ }^{19}$ and the lack of appropriate measures to reduce exposure, show they lack knowledge concerning the intake of benzene. In this context, we agree with studies ${ }^{19,23}$ highlighting the importance of using PPE and encouraging serious individual and collective care measures among workers, such as avoiding drying hands on one's uniform; using gloves to fuel vehicles instead of rags that remain out at the lane; washing hands frequently and before eating; not rolling up the uniform's sleeves, among other measures. Other measures related to work conditions can minimize exposure, such as providing sinks for the external areas near the fueling area for workers to wash their hands.

\section{FINAL CONSIDERATIONS}

This study's results enabled the identification of the socio-demographic profile of gas station workers; showed that most workers perform multiple tasks; and also enabled the identification of how long these individuals have worked in the sector and have performed their job functions, which requires care due to cumulative exposure. The weekly workload is long and wages are low, even after adding hazard pay. We note the use of PPE such as boots, aprons, gloves and uniforms on the part of the gas station workers, though some deny the use of PPE. Observation confirmed the use of boots and uniform, however, other devices were not used, even if available. Therefore, the responsibility of employers is not only to provide PPE, but also enforce and monitor the use of PPE, while workers are responsible for appropriately using the protective measures provided. In this aspect, we noticed a lack of coherence between the workers' reports and what was observed during working hours, showing a lack of knowledge of the risks and diseases to which they are exposed in the work environment.

We note the need for further studies to more incisively intervene in the occupational health of gas station workers. Another relevant aspect involves the fact that observation was not performed during all work shifts (e.g. night shift) due to safety and financial reasons, which can be considered a limitation of this study.

The practice of nurses comprises measures that encourage workers to adopt measures to protect their health while in the workplace based on guidance as to how contamination by chemical agents takes place; how to eliminate such elements from the organism and how to avoid exposure; which PPE is appropriate and should be used during working hours. These actions can be implemented by nurses linked to Regional Centers in Occupational Health (CEREST, as per its acronym in Portuguese), the objective of which is to prevent occupational accidents and diseases. Hence, the CEREST covering this region is a strategic tool to disseminate occupational health practices within the SUS network's sphere through interventions, surveillance of disease and working conditions in order to minimize or eliminate the exposure of workers to occupational risks.

\section{ACKNOWLEDGEMENTS}

To the National Council for Scientific and Technological Development (CNPq) for the financial support of the project "Health promotion, risks and occupational diseases - integrated study in different workplaces", submitted to Universal 14/2011 (Process n. 483853/2011-9). 


\section{REFERENCES}

1. Cezar-Vaz MR, Rocha LP, Bonow CA, Silva MRS, Cezar-Vaz J, Cardoso LS. Risk perception and occupational accidents: a study of gas station workers in southern Brazil. Int J Environ Res Public Health. 2012 Jul; 9(7):2362-77.

2. Ferreira MC, Freire ON. Carga de trabalho e rotatividade na função de frentista. Rev Adm Contemp. 2001 Mai-Ago; 5(2):175-200.

3. Ministério da Saúde (BR). Secretaria de Atenção à Saúde. Instituto Nacional do Câncer. Coordenação de Prevenção e Vigilância. Vigilância do câncer ocupacional e ambiental. Rio de Janeiro (RJ): INCA; 2005.

4. Ministério da Saúde (BR). Secretaria de Políticas de Saúde. Departamento de Atenção Básica. Área Técnica de Saúde do Trabalhador. Cadernos de Atenção Básica: Programa Saúde da Família. Brasília (DF): MS; 2001.

5. Costa MAF, Costa MFB. Benzeno: uma questão de saúde pública. Interciência. 2002 Abr; 27(4):201-4.

6. Dib MA, Oliveira LRZ, Dias OA, Torres ARR, Silveira NA. Avaliação da qualidade do sêmen e do estado geral de saúde de frentistas de postos de gasolina da cidade de Goiânia. Estudos. 2007 Nov-Dez; 34(11-12):957-77.

7. Machado JMH, Costa DF, Cardoso LM, Arcuri A. Alternativas e processos de vigilância em saúde do trabalhador relacionados à exposição ao benzeno no Brasil. Ciênc Saúde Coletiva. 2003 Out-Dez; 8(4):913-21.

8. Ministério do Trabalho e Emprego (BR). Portaria Interministerial n. 775, de 28 de abril de 2004. Dispõe sobre a proibição da comercialização de produtos acabados que contenham "benzeno" em sua composição, admitindo, porém, alguns percentuais [Internet]. Brasília (DF); 2004 [aceso 2011 Set 22]. Disponível em: http://portal.mte. gov.br/legislacao/ portaria-interministerial-n775-de-28-04-2004.htm

9. Cezar-Vaz MR, Cardoso LS, Bonow CA, Sant' Anna $\mathrm{CF}$, Sena J. Conhecimento clínico do enfermeiro na atenção primária à saúde: aplicação de uma matriz filosófica de análise. Texto Contexto Enferm. 2010 Jan-Mar; 19(1):17-24.

10. Brasil. Organização Pan-Americana da Saúde no Brasil. Doenças relacionadas ao trabalho: manual de procedimentos para os serviços de saúde. Brasília (DF): MS; 2001.

11. Ministério do Trabalho e do Emprego (BR). Legislação de Segurança e Medicina do Trabalho. $2^{a}$ ed. São Paulo (SP): Método; 2008.
12. Silveira FL. Um exemplo de análise multivariada aplicada à pesquisa quantitativa em ensino de ciências: explicando o desempenho dos candidatos ao concurso vestibular de 1999 da Universidade Federal do Rio Grande do Sul. Investigações Ensino Ciências. 1999; 4(2):161-80.

13. Silverman D. Interpretação de dados qualitativos: métodos para análise de entrevistas, textos e interações. Porto Alegre (RS): Artmed, 2009.

14. Grendel GL, Teixeira M L. Avaliação de acido hipúrico como biomarcador de exposição ocupacional em trabalhadores de postos de combustíveis. Rev Saúde Pesquisa. 2009 Set-Dez; 2(3):319-24.

15. Bloemen LJ, Youk A, Bradley TD, Bodner KM, Marsh G. Lymphohaematopoietic cancer risk among chemical workers exposed to benzene. Occup Environ Med. 2004 Mar; 61(3):270-4.

16. Chen D, Cho S-I, Chen C, Wang X, Damokosh AI, Ryan L, et. al. Exposure to benzene, occupational stress, and reduced birth weight. Occup Environ Med. 2000 Out; 57(10):661-7.

17. Ministério do Trabalho e do Emprego (BR). Consolidação das Leis de Trabalho. Decreto-Lei n. 5.452 , de $1^{\circ}$ de maio de 1943 . Aprova a Consolidação das Leis de Trabalho [Internet]. [acesso $2011 \mathrm{Mar}$ 22]. Disponível em: https://www.planalto.gov. br/ccivil_03/decreto-lei/Del5452.htm

18. Ministério do Trabalho e do Emprego (BR). Consolidação das Leis de Trabalho. Convenção coletiva de trabalho [Internet]. 2011 [acesso 2011 Mai 25]. Disponível em: http:/ / portal.mte.gov.br/data/files / FF8080812C1CBDF2012C2172CC301BE6/SIND_ COMBUST_2005.pdf

19. Colman R, Coleman A. Unexpected cause of raised benzene absorption in coke oven byproduct workers. Occup Med (Lond). 2006 Jun; 56(4):269-71.

20. Adami G, Larese F, Venier M, Barbieri P, Lo Coco F, Reisenhofer E. Penetration of benzene, toluene and xylenes contained in gasolines through human abdominal skin in vitro. Toxicol in Vitro. 2006 Dez; 20(8):1321-30.

21. Carvalho QGS, Pedrosa WA, Sebastião QP. Leucemia mieloide aguda versus ocupação profissional: perfil dos trabalhadores atendidos no hospital de hematologia de Recife. Rev Esc Enferm USP. 2011 Dez; 45(6):1446-51.

22. Soares JFS, Cezar-Vaz MR, Sant'Anna CF. Injury prevention and health promotion: a study among dock workers. Texto Contexto Enferm. 2011 JulSet; 20(3):425-34. 
23. Wiwanitkit V, Suwansaksri J, Nasuan P. Research note: urine trans, trans-muconic acid as a biomarker for benzene exposure in gas station attendants in Bangkok, Thailand. Ann Clin Lab Sci. 2001 Out; 31(4):399-401.

$4^{\circ}$ andar - Escola de Enfermagem

Rua: General Osório, s/n.

96200-190 - Rio Grande, RS, Brasil

E-mail: laurelize@gmail.com 